\title{
Persepsi Etis Mahasiswa Akuntansi Atas Perilaku Tidak Etis Akuntan
}

\author{
Kadek Indah Dwi Lestari ${ }^{1}$ \\ I Wayan Ramantha ${ }^{2}$
}

\author{
${ }^{1,2}$ Fakultas Ekonomi dan Bisnis Universitas Udayana (Unud), Bali, Indonesia \\ e-mail: lestariindah213@gmail.com
}

\begin{abstract}
ABSTRAK
Tujuan penelitian untuk mengetahui pengaruh pengetahuan etika, idealisme, relativisme dan gender pada persepsi etis mahasiswa akuntansi atas perilaku tidak etis akuntan. Penelitian ini dilakukan di Fakultas Ekonomi dan Bisnis Universitas Udayana. Jumlah sampel yang digunakan berjumlah 94 mahasiswa akuntansi dengan teknik analisis regresi linier berganda. Berdasarkan hasil penelitian ditemukan bahwa pengetahuan etika dan idealisme berpengaruh negatif pada persepsi etis mahasiswa akuntansi atas perilaku tidak etis akuntan Hal ini menunjukkan semakin tinggi pengetahuan etika dan idealisme yang dimiliki mahasiswa maka semakin tidak setuju dengan adanya perilaku etis akuntan. Relativisme berpengaruh positif pada persepsi etis mahasiswa akuntansi atas perilaku tidak etis akuntan. Hal ini menunjukkan semakin tinggi relativisme yang dimiliki mahasiswa maka semakin setuju dengan perilaku etis akuntan. Gender berpengaruh negatif tetapi tidak signifikan pada persepsi etis mahasiswa akuntansi atas perilaku tidak etis akuntan. Hal ini menunjukkan bahwa laki-laki dan perempuan memberikan sikap ketidaksetujuan dengan perilaku tidak etis akuntan.
\end{abstract}

Kata kunci: Pengetahuan etika, idealisme, relativisme, gender, persepsi etis, mahasiswa akuntansi, perilaku tidak etis

\begin{abstract}
The research objective was to determine the effect of knowledge of ethics, idealism, relativism and gender on accounting students 'ethical perceptions of accountants' unethical behavior. This research was conducted at the Faculty of Economics and Business, Udayana University. The number of samples used amounted to 94 accounting students with multiple linear regression analysis techniques. Based on the results of the study it was found that knowledge of ethics and idealism negatively affected accounting students' ethical perceptions of accountant's unethical behavior. This shows that the higher the knowledge of ethics and idealism that students have, the more they disagree with the ethical behavior of accountants. Relativism has a positive effect on accounting students 'ethical perceptions of accountants' unethical behavior. This shows that the higher the relativism that students have, the more they agree with the ethical behavior of accountants. Gender has a negative but not significant effect on accounting students 'ethical perceptions of accountants' unethical behavior. This shows that men and women give an attitude of disagreement with accountants' unethical behavior.
\end{abstract}

Keywords: Ethical knowledge, idealism, relativism, gender, ethical perceptions, accounting students, unethical behaviour

\section{PENDAHULUAN}

Perkembangan globaliasi saat ini menuntut manusia untuk lebih cerdas dan kreatif dalam segala bidang. Semakin meningkatnya kecerdasan manusia tidak hanya menimbulkan dampak yang positif melainkan juga menimbulkan dampak yang 
negative Diwi (2015). Perkembangan globalisasi yang terjadi mengubah gaya hidup dan pola pikir sehingga seringkali mendorong orang untuk melakukan tindakan-tindakan yang mengabaikan moral dan etika. Bahkan cenderung menghalalkan segala cara tanpa memikirkan dampak atas perbuatan tersebut. Oleh karenanya etika muncul sebagai salah satu faktor menarik dalam era globalisasi saat ini.

Etika dan aturan dalam profesi di bidang akuntansi harus dipatuhi oleh pihak-pihak yang ada dalam profesi tersebut. Etika merupakan nilai atau norma yang dijadikan pegangan oleh individu atau masyarakat untuk mengatur tingkah lakunya (Bertens, 2013). Etika profesi khusus berlaku dalam kelompok profesi yang bersangkutan, dimana dalam penelitian ini adalah akuntan.

Akuntan adalah mereka yang telah lulus dari pendidikan strata satu (S1) program studi akuntansi dan telah memperoleh gelar profesi akuntan melalui pendidikan profesi akuntansi (PPAk). Sampai saat ini banyak profesi yang dapat digeluti oleh akuntan, yaitu sebagai akuntan manajemen (auditor internal), akuntan pemerintah, akuntan publik (auditor eksternal), akuntan pendidik dan sebagainya.

Tujuan profesi akuntansi adalah untuk memenuhi tanggung jawab dengan standar profesionalisme tertinggi dan mencapai tingkat kinerja tertinggi dengan orientasi kepada kepentingan publik. Terdapat empat kebutuhan dasar untuk memenuhi tujuan tersebut yaitu kredibilitas, profesionalisme, kualitas jasa dan kepercayaan. Jika hal tersebut tidak dipenuhi, maka dapat menimbulkan krisis kepercayaan terhadap profesi akuntansi. Selanjutnya, Chan dan Leung (2006) 
menyatakan bahwa profesi akuntansi rentan terhadap pelanggaran etika. Pelanggaran etika yang dilakukan oleh akuntan menurunkan kepercayaan masyarakat terhadap profesi ini. Hal tersebut menjadikan profesionalisme dan perilaku etis dalam suatu profesi dipertanyakan oleh masyarakat (Herwinda, 2010).

Perilaku etis adalah perilaku ketika seseorang dapat bertindak sesuai dengan hukum, peraturan, dan moral yang telah ditetapkan (Yunus, 2011). Perilaku etis sangat penting untuk diterapkan di setiap bidang profesi. Larkin (2000) setiap profesi tidak hanya harus memiliki kapasitas, tetapi juga harus memiliki etika yang digunakan sebagai acuan. Kode etik profesi ditetapkan untuk memperoleh kesamaan penilaian terkait etis tidaknya suatu tindakan. Pambudi (2014) menyatakan penerapan kode etik profesi dalam setiap jenis profesi menjadi hal yang penting dilakukan, kode etik profesi hadir untuk mengatur mereka yang menggeluti profesi tertentu agar apa yang dikerjakan sesuai dengan prosedur dan tidak merugikan orang lain.

Pembahasan mengenai kode etik profesi akuntan didasarkan pada Kode Etik Ikatan Akuntan Indonesia yang ditetapkan dalam Kongres IAI ke-VIII tahun 1998 (Mulyadi, 2014:50). Prinsip etika profesi IAI yang telah diputuskan dalam Kongres IAI ke-VIII tahun 1998, yaitu meliputi tanggung jawab profesi, kepentingan publik, integritas, obyektivitas, kompetensi dan kehati-hatian profesional, kerahasiaan, perilaku profesional, dan standar teknis. Delapan prinsip etika tersebut sangat diperlukan sebagai pedoman kerja seorang akuntan professional (Mulyadi, 2014:53-60). Menjaga kode etik profesi menjadi hal yang 
mutlak dilakukan oleh profesi akuntan karena berdasarkan prinsip akuntansi, kode etik akuntan harus lebih dikedepankan dibanding kepentingan perusahaan. Namun pada praktiknya masih banyak oknum akuntan yang bekerja tanpa memperhatikan kode etik yang ada.

Dewasa ini bermunculan berbagai kasus tentang perilaku tidak etis yang melibatkan akuntan. Perilaku tidak etis adalah perilaku seseorang yang bertindak tidak sesuai aturan, hukum maupun moral (Damayanthi, 2016). Karakter pribadi yang individual, materialis dan kapitalis mendorong seseorang untuk melakukan hal-hal negatif tanpa memikirkan dampak atas perbuatannya. Persaingan kerja yang begitu ketat membuat munculnya kasus-kasus tentang perilaku tidak etis akuntan salah satunya yang terkenal adalah kasus Enron dengan KAP Arthur Andersen yang telah menghebohkan percaturan bisnis global. Fortune 500 yang dilansir Communale et. al., (2006) mengungkapkan bahwa Enron adalah satu dari tujuh perusahaan besar di Amerika yang terlibat kasus dalam bidang akuntansi. Perusahaan ini bergerak di bidang industri energi, dimana para manajernya melakukan manipulasi angka yang menjadi dasar untuk memperoleh kompensasi moneter yang besar. Kasus ini diperparah dengan praktik akuntansi yang meragukan dan tidak independennya audit yang dilakukan oleh Kantor Akuntan Publik (KAP) Arthur Andersen terhadap Enron Corp (Hutahahean 2015). Dalam hal ini Arthur Andersen sebagai auditor independen yang memberikan jasa audit atas laporan keuangan perusahaan Enron, telah melakukan pelanggaran atas kode etik profesional akuntan dengan merekayasa laporan keuangan Enron dan lebih parahnya lagi Arthur Andersen menghancurkan dokumen-dokumen penting 
terkait dengan bukti audit Enron. Selain itu, terdapat kasus Tesco yang terjadi pada akhir tahun 2014 yang lalu, terbukti bahwa pihak manajemen perusahaan Tesco ditemukan menggelembungkan labanya sehingga meningkat hingga $£ 250$ Miliar selama hanya setengah tahun.

Kasus tentang perilaku tidak etis yang melibatkan akuntan tidak hanya terjadi di luar Indonesia. Hal tersebut juga terjadi di Indonesia salah satunya di perusahaan PT. Great River International Tbk. Agoes dan Ardana (2009) menyebutkan bahwa berdasarkan hasil pemeriksaan Bapepam, ada indikasi konspirasi dalam penyajian laporan keuangan Great River yang dilakukan oleh Akuntan Publik yang memeriksa laporan keuangan tersebut. Bapepam menemukan kelebihan pencatatan atau overstatement penyajian akun penjualan dan piutang dalam laporan tersebut, sehingga mengakibatkan perusahaan mengalami kesulitan dalam arus kas untuk membayar hutang Rp 250 Milyar kepada Bank Mandiri dan gagal membayar obligasi senilai Rp 300 Milyar. Akuntan Publik yang mengaudit laporan keuangan Great River tahun 2003 menyatakan alasan dugaan overstatement karena pencatatan untuk akun penjualan menggunakan metode yang berbeda dari ketentuan yang ada. Perusahaan mencantumkan biaya bahan baku agar saldo laba bersih tidak berbeda dengan yang diterima perusahaan untuk menghindari dugaan dumping dan sanksi perpajakan.

Berbagai kasus yang terjadi dengan keterlibatan akuntan didalamnya telah menimbulkan reaksi dalam bentuk opini maupun persepsi pada diri mahasiswa khususnya mahasiswa akuntansi (Reni Yendrawati, 2013). Mahasiswa 
akuntansi berperan penting dalam memberikan tanggapan atas berbagai fenomena yang terjadi di sekitar masyarakat karena mereka memiliki pengetahuan yang cukup terkait dengan etika. Menurut Griffin (2014) salah satu keahlian intelektual yang harus dimiliki oleh mahasiswa akuntansi adalah kemampuan untuk mengidentifikasi isu-isu etis berbeda-beda, meskipun mereka telah diberikan pengetahuan dengan porsi yang sama.

Hasil penelitian Communale et. al., (2006) menyatakan bahwa pengetahuan dan informasi yang dimiliki mahasiswa akan mempengaruhi persepsi mereka terhadap perilaku tidak etis akuntan. Mahasiswa yang memiliki pengetahuan etika yang tinggi maka akan membantu mereka untuk dapat memberikan persepsi maupun tanggapan terhadap perilaku tidak etis yang melibatkan profesi akuntan tersebut. Namun dengan banyaknya informasi yang diperoleh dari media mengenai berbagai kasus perilaku tidak etis akuntan dapat menimbulkan persepsi negatif mahasiswa terhadap profesi akuntan. Menurut penelitian Putra dan Baridwan (2012) menyatakan bahwa pengetahuan berpengaruh negatif pada persepsi mahasiswa akuntansi atas perilaku tidak etis akuntan, mahasiswa dalam menanggapi perilaku tidak etis akuntan cenderung memberikan persepsi negatif atau ketidaksetujuan akan hal tersebut. Hal ini didukung oleh hasil penelitian Dzakirin (2013) bahwa tingkat pengetahuan berpengaruh negatif terhadap persepsi mahasiswa atas krisis etika akuntan professional. Tetapi hal tersebut tidak sejalan dengan penelitian Nugroho (2008) dan Muhammad (2013) menyatakan bahwa pengetahuan tidak mempengaruhi persepsi mahasiswa terhadap perilaku tidak etis akuntan. Mahasiswa yang 
memiliki pengetahuan tentang etika profesi akuntan cenderung lebih menyalahkan manajemen suatu perusahaan daripada akuntan itu sendiri.

Idealisme dan relativisme pada dasarnya adalah dua aspek filosofi moral seorang individu. Menurut Forsyth (1992) menjelaskan bahwa idealisme merupakan dimensi yang menggambarkan ideologi etika, individu yang memiliki ideologi etika idealisme harus memastikan apa yang dilakukan tidak akan menimbulkan dampak yang negatif bagi orang disekelilingnya serta berprinsip untuk selalu megedepankan kebenaran dan kebaikan. Penelitian yang dilakukan oleh Mardawati (2014) hasilnya menunjukkan bahwa idealisme berpengaruh negatif pada persepsi mahasiswa terhadap perilaku tidak etis akuntan. Hal ini sejalan dengan hasil penelitian Dzakirin (2013) yang menyatakan bahwa tingkat idealisme berpengaruh negatif terhadap persepsi mahasiswa atas krisis etika akuntan professional. Mahasiswa dengan idealisme tinggi akan menilai perilaku tidak etis akuntan secara lebih tegas dan menunjukkan ketidaksetujuan terhadap perilaku tersebut. Namun, hal ini tidak sejalan dengan penelitian yang dilakukan oleh Nugroho (2008) yang menyatakan bahwa tingkat idealisme tidak berpengaruh pada persepsi mahasiswa terhadap tindakan auditor, sehingga mahasiswa yang memiliki tingkat idealisme yang tinggi belum tentu akan menilai pelanggaran etika auditor dengan lebih tegas.

Relativisme adalah orientasi etika yang mengacu pada penolakan nilainilai moral yang membimbing perilaku individu. Relativisme merasakan bahwa etika sifatnya tidak universal karena etika dilatarbelakangi oleh budaya dimana masing-masing budaya memiliki aturan yang berbeda-beda. Individu yang 
memiliki ideologi etika relativisme cenderung akan menolak aturan moral secara universal ketika dihadapkan oleh pertanyaan-pertanyaan moral. Menurut Forsyth (1992) individu relativis tidak memperhatikan prinsip-prinsip yang berlaku sehingga individu relativis akan melihat keadaan sekitar terlebih dahulu sebelum merespon ataupun bertindak jika menemukan pelanggaran etika. Penelitian yang dilakukan oleh Forsyth (1992) sejalan dengan penelitian Reni Yendrawati (2013), Sutiarsih, G.A (2014) dan Damayanthi (2016) yang menunjukan bahwa mahasiswa yang memilliki relativisme yang tinggi cenderung memberikan persepsi positif terhadap perilaku tidak etis akuntan. Disamping orientasi etis yaitu idealisme dan relativisme yang dapat mempengaruhi persepsi etis mahasiswa akuntansi atas perilaku tidak etis akuntan, gender juga dapat mempengaruhi persepsi mereka setelah mengetahui adanya perilaku tidak etis yang melibatkan profesi akuntan.

Perbedaan gender dapat memberikan penilaian berbeda dalam melihat perilaku tidak etis yang melibatkan profesi akuntan. Penelitian yang dilakukan oleh Joseph (2010) menyatakan bahwa mahasiswa perempuan secara signifikan lebih etis daripada rekan laki-laki mereka. Penelitian lain yang dilakukan oleh Sankaran, S and Bui (2003) juga menunjukan bahwa ada pengaruh signifikan antara perempuan dan laki-laki. Perempuan akan berpersepsi lebih tegas terhadap perilaku tidak etis dibandingkan dengan laki-laki. Sedangkan penelitian yang dilakukan oleh Siti Muthmainah. (2006), Diwi (2015) dan Damayanthi (2016) menunjukkan hasil yang berbeda. Penelitian yang dilakukan ketiganya 
menunjukkan tidak adanya perbedaan yang signifikan antara perempuan dan lakilaki dalam memberikan penilaian terhadap perilaku tidak etis akuntan

Penelitian ini menganalisis mengenai pengaruh pengetahuan etika, idealisme, relativisme, dan gender terhadap persepsi etis mahasiswa akuntansi atas perilaku tidak etis akuntan. Penekanan penelitian ini adalah pada dimensi aspek demografi yang meliputi pengetahuan etika, idealisme, relativisme, dan gender sebagai bagian dari aspek individual yang dapat mempengaruhi persepsi etis mahasiswa akuntansi atas perilaku tidak etis akuntan. Penelitian ini dilakukan karena adanya krisis kepercayaan masyarakat terhadap profesi akuntansi dan untuk mendeteksi kembali apakah pengetahuan etika, idealisme, relativisme, dan gender mampu mempengaruhi persepsi etis seseorang atas perilaku tidak etis akuntan, terutama pada mahasiswa akuntansi sebagai calon akuntan profesional. Pengetahuan merupakan informasi yang dimiliki atau diketahui secara sadar atau tidak. Pengetahuan dapat pula dikatakan sebagai berbagai gejala yang ditemui dan diperoleh manusia melalui pengamatan akal. Pengetahuan yang dimaksudkan disini, berkaitan dengan informasi mengenai prinsip etika yang berlaku dalam profesi akuntan. Pengetahuan mengenai etika yang diterima antara mahasiswa satu dengan yang lainnya tentu berbeda. Hal ini dipengaruhi pula oleh lama kuliah dan jumlah mata kuliah yang telah ditempuh. Mahasiswa tingkat atas umumnya memiliki pengetahuan yang lebih luas dibandingkan dengan mahasiswa yang berada ditingkat bawahnya.

Akbar (2013) menjelaskan sebagai calon akuntan, mahasiswa akuntansi perlu memahami etika profesi akuntan sejak dini, mahasiswa 
akuntansi juga harus dapat bersikap secara profesional untuk membuktikan bahwa profesi akuntan merupakan profesi yang memiliki etika tinggi dan mampu bekerja tanpa berpihak untuk kepentingan satu pihak saja. Pengetahuan etika seharusnya dapat membantu mahasiswa menjadi lebih siap dalam menghadapi permasalahan etika yang ada didunia kerja. Pemahaman yang memadai terkait dengan etika khusunya etika pada profesi tertentu akan membantu setiap individu untuk bisa menyesuaikan diri dengan baik di lingkungannya (Ziegenfuss, D. E. and Martinson, 2002).

Mahasiswa yang memiliki pengetahuan yang luas mengenai prinsip etika profesi akuntan akan bersikap lebih bijaksana dan memberikan tanggapan berupa ketidaksetujuan mengenai skandal etis yang menimpa profesi akuntan berkaitan dengan penerapan prinsip etika profesi akuntan dibandingkan dengan mahasiswa yang memiliki pengetahuan lebih sedikit.

Penelitian yang dibuat oleh Dzakirin (2013) menunjukan bahwa tingkat pengetahuan berpengaruh negatif terhadap persepsi mahasiswa atas krisis etika akuntan profesional. Sejalan dengan hal tersebut, penelitian yang dilakukan oleh Damayanthi (2016), Mardawati (2014), dan Himmah (2006) juga menyebutkan bahwa tingkat pengetahuan yang dimiliki mahasiswa memberikan tanggapan negatif atas perilaku tidak etis yang dilakukan akuntan. Berdasarkan penjelasan diatas dapat disimpulkan bahwa semakin tinggi dan luas pengetahuan yang dimiliki mengenai etika profesi akuntan maka seorang mahasiswa akan memberikan reaksi ketidaksetujuan terhadap perilaku tidak etis akuntan. 
Berdasarkan uraian diatas dan penelitian sebelumnya, dapat dirumuskan hipotesis pertama sebagai berikut.

$\mathrm{H}_{1}$ : Pengetahuan etika berpengaruh negatif pada persepsi etis mahasiswa akuntansi atas perilaku tidak etis akuntan.

Idealisme merupakan salah satu filosofi moral individu, dimana individu yang idealis akan cenderung menghindari berbagai tindakan yang dapat menyakiti maupun merugikan orang lain. Forsyth (1992) menyatakan bahwa seorang yang idealis akan mengambil tindakan tegas terhadap suatu kejadian yang tidak etis ataupun yang merugikan orang lain. Individu yang idealis akan mengambil tindakan tegas pada situasi yang dapat menimbulkan kerugian terhadap orang lain dan memiliki sikap serta pandangan yang lebih tegas terhadap individu yang melanggar perilaku etis dalam profesinya.

Penelitian yang dilakukan oleh Nugroho (2008) membuktikan bahwa idealisme tidak menunjukkan pengaruh yang signifikan terhadap persepsi mahasiswa akuntansi atas tindakan auditor dalam skandal keuangan. Hal ini tidak sejalan dengan penelitian yang dibuat oleh Diwi (2015), Mardawati (2014) dan Nurcahyo (2012), menunjukan bahwa mahasiswa yang memiliki idealisme yang tinggi cenderung memberikan tanggapan/ persepsi negatif terhadap perilaku tidak etis akuntan. Hal ini dapat terjadi akibat pemahaman mahasiswa mengenai etika dan proses pembelajaran etika yang efektif, sehingga ketika dihadapkan kepada sebuah perilaku tidak etis mahasiswa cenderung memberikan persepsi atau penilaian yang tegas.

Berdasarkan uraian diatas dan penelitian sebelumnya, dapat dirumuskan hipotesis kedua sebagai berikut. 
$\mathrm{H}_{2}$ : Idealisme berpengaruh negatif terhadap persepsi etis mahasiswa akuntansi atas perilaku tidak etis akuntan.

Relativisme merupakan salah satu filsafat moral yang mendukung skeptisme. Seorang yang bersifat relativis umumnya merasa bahwa tindakan moral tergantung pada situasi dan individu yang terlibat. Individu yang relativis justru tidak mengindahan prinsip-prinsip yang ada dan lebih melihat keadaan sekitar sebelum akhirnya bertindak merespon suatu kejadian yang melanggar etika.

Individu dengan tingkat relativisme yang tinggi cenderung menolak gagasan mengenai kode moral. Relativisme beranggapan bahwa tidak ada standar etis yang secara absolute benar dan ia selalu mengikuti standar moral yang berlaku dalam masyarakat dimanapun ia berada (Widiastuti, 2015). Jika individu relativis dihadapkan pada situasi yang tidak etis, maka mereka akan memberikan tanggapan yang berbeda dari individu yang idealis. Mereka akan lebih melihat situasi dan individu yang terlibat kemudian memberikan respon.

Penelitian yang dilakukan oleh Nugroho (2008) menyatakan bahwa relativisme tidak berpengaruh secara signifikan terhadap persepsi mahasiswa akuntansi atas tindakan auditor dalam skandal keuangan. Hal ini sejalan dengan penelitian Communale et. al., (2006) dalam Dzakirin (2013) menyatakan bahwa relativisme tidak memiliki pengaruh yang positif terhadap persepsi mahasiswa tentang skandal Enron. Namun hasil penelitian ini tidak sejalan dengan penelitian yang dilakukan oleh Sutiarsih (2014), Fitria (2015) dan Damayanthi (2016) yang menunjukan bahwa mahasiswa yang memilliki orientasi relativisme yang tinggi cenderung memberikan persepsi positif terhadap 
perilaku tidak etis akuntan. Secara teori, seseorang yang memiliki tingkat relativisme tinggi akan memiliki persepsi etis yang rendah terhadap perilaku tidak etis yang terjadi.

Berdasarkan uraian diatas dan penelitian sebelumnya, dapat dirumuskan hipotesis ketiga sebagai berikut.

$\mathrm{H}_{3}$ : Relativisme berpengaruh positif terhadap persepsi etis mahasiswa akuntansi atas perilaku tidak etis akuntan.

Gender sering diinterpretasikan sebagai pembeda jenis kelamin antara laki-laki dan perempuan. Gender juga dapat diasosiasikan sebagai suatu konsep analisis yang digunakan untuk mengidentifikasi perbedaan antara laki-laki dan perempuan yang dilihat dari sudut non-biologis, yaitu aspek sosial, budaya maupun psikologis.

Laki-laki dan perempuan umumnya memiliki cara pandang yang berbeda dalam melihat suatu hal (Hunt, 2009). Terkadang laki-laki lebih bersifat relativis dibandingkan perempuan. Laki-laki biasanya akan lebih bersikap rasional dalam menghadapi suatu permasalahan dan cenderung menyukai tantangan. Sedangkan perempuan bersikap sebaliknya, dalam menghadapi sebuah permasalahan biasanya perempuan akan lebih emosional dan menghindari masalah. Oleh karena itu, dalam membuat keputusan berkaitan dengan penilaian etis perempuan akan cenderung lebih tegas dalam menyikapi hal-hal yang tidak etis yang terjadi disekitarnya dibandingkan dengan laki-laki. Hal tersebut mengindikasikan bahwa perbedaan gender berakibat pada penilaian yang berbeda antara laki-laki dan perempuan dalam 
menilai perilaku tidak etis yang ada, terutama perempuan akan berpersepsi lebih etis dalam menilai perilaku tidak etis yang terjadi.

Penelitian yang dilakukan oleh Sari (2010) menyebutkan bahwa gender memiliki pengaruh terhadap pemahaman etika dalam penerapan perilaku etis. Penelitian Sankaran and Bui (2003) bahwa mahasiswa yang bergender wanita akan lebih bepersepsi tegas terhadap pelanggaran etika yang dilakukan oleh akuntan. Penelitian yang dilakukan oleh Darsinah (2005) dan Himmah (2006) juga menyatakan gender memiliki pengaruh karena ada perbedaan sensitivitas etis yang signifikan antara mahasiswa laki-laki dengan perempuan dalam menyikapi perilaku tidak etis akuntan.

Berdasarkan uraian diatas dan penelitian sebelumnya, dapat dirumuskan hipotesis keempat sebagai berikut.

$\mathrm{H}_{4}$ : Gender berpengaruh terhadap persepsi etis mahasiswa akuntansi atas perilaku tidak etis akuntan.

\section{METODE PENELITIAN}

Lokasi Penelitian merupakan suatu tempat dimana penelitian dilakukan. Penelitian ini berlokasi di Fakultas Ekonomi dan Bisnis Universitas Udayana. Populasi yang digunakan dalam penelitian ini adalah mahasiswa S1 akuntansi di Universitas Udayana. Populasi dalam penelitian ini berjumlah 1463 mahasiswa aktif yang terdiri dari angkatan 2014, 2015, 2016, 2017 dan 2018. Berdasarkan perhitungan rumus Slovin, diperoleh hasil bahwa jumlah sampel minimal yang dapat digunakan dalam penelitian ini sebesar 94 orang mahasiswa akuntansi. 
Teknik analisis data yang dipergunakan untuk memecahkan masalah dalam penelitian ini adalah teknik analisis regresi linear berganda. Adapun model regresi dalam penelitian ini dinyatakan sebagai berikut:

$\mathrm{Y}=\alpha+\beta_{1} \cdot \mathrm{X}_{1}+\beta_{2} \cdot \mathrm{X}_{2}+\beta_{3} \cdot \mathrm{X}_{3}+\beta_{4} \cdot \mathrm{X}_{4}+\square$

Keterangan:

$\mathrm{Y}=$ Persepsi etis mahasiswa akuntansi atas perilaku tidak etis akuntan

$\alpha \quad=$ Nilai Konstanta

$\beta_{1} \beta_{2} \beta_{3} \beta_{4} \quad=$ Koefisien regresi variabel independen

$\mathrm{X}_{1} \quad=$ Pengetahuan Etika

$\mathrm{X}_{2} \quad=$ Idealisme

$\mathrm{X}_{3} \quad=$ Relativisme

$\mathrm{X}_{4} \quad=$ Gender

= Error term, yaitu tingkat kesalahan penduga dalam penelitian.

\section{HASIL DAN PEMBAHASAN}

Berdasarkan Tabel 1 dapat dilihat banyaknya kuesioner yang diolah sebanyak 94 kuesioner untuk masing-masing variabel. Adapun hasil statistik dekriptif adalah sebagai berikut variabel Pengetahuan Etika $\left(\mathrm{X}_{1}\right)$ terdiri dari 16 pernyataan mengenai etika profesi akuntansi yang terdiri atas 8 indikator. Penilaian skor menggunakan skala Likert 1-4, dengan ketentuan semakin besar skor yang diperoleh mengindikasikan bahwa responden memiliki pengetahuan etika tinggi. Demikian sebaliknya, semakin kecil nilai yang diperoleh, maka responden memiliki tingkat pengetahuan etika yang rendah. Tabel 4.11 menunjukkan bahwa variabel pengetahuan etika $\left(\mathrm{X}_{1}\right)$ memiliki nilai rata-rata sebesar 46,4130 dengan nilai minimum 17,29 dan nilai maksimum 59,62. Hal ini menunjukkan bahwa mahasiswa akuntansi di Fakultas Ekonomi dan Bisnis Universitas Udayana memiliki pengetahuan etika yang cukup tinggi terhadap 
etika profesi akuntansi karena dapat dilihat nilai rata-rata lebih mendekati nilai maksimal, yang artinya sebagian besar responden cenderung menjawab setuju pada ke-16 item pernyataan dalam variabel pengetahuan etika. Nilai standar deviasi yang dimiliki oleh pengetahuan etika adalah 13,32641 dimana lebih kecil dari nilai rata-ratanya yaitu 46,4130, sehingga mengindikasikan bahwa hasil yang cukup baik. Hal tersebut dikarenakan standar deviasi adalah pencerminan penyimpangan yang sangat tinggi, sehingga penyebaran data menunjukkan hasil yang normal dan tidak menyebabkan bias.

Tabel 1.

Hasil Statistik Deskriptif

\begin{tabular}{lccccc}
\hline \multicolumn{1}{c}{ Variabel } & $\mathrm{N}$ & Minimum & Maximum & Mean & $\begin{array}{c}\text { Std. } \\
\text { Deviation }\end{array}$ \\
\hline Pengetahuan Etika $\left(\mathrm{X}_{1}\right)$ & 94 & 17,29 & 59,62 & 46,4130 & 13,32641 \\
Idealisme $\left(\mathrm{X}_{2}\right)$ & 94 & 10,00 & 37,38 & 29,6081 & 8,52740 \\
Relativisme $\left(\mathrm{X}_{3}\right)$ & 94 & 12,12 & 52,18 & 22,0654 & 7,27105 \\
Gender $\left(\mathrm{X}_{4}\right)$ & 94 & 1,00 & 2,00 & 1,4255 & 0,49707 \\
Persepsi etis mahasiswa & 94 & 5,00 & 21,95 & 11,3420 & 3,90937 \\
akuntansi atas perilaku & & & & \\
tidak etis akuntan $(\mathrm{Y})$ & & & &
\end{tabular}

Variabel idealisme $\left(\mathrm{X}_{2}\right)$ terdiri dari 10 pernyataan mengenai pendapat responden dalam menilai suatu tindakan. Penilaian skor menggunakan skala Likert 1-4, dengan ketentuan semakin besar skor yang diperoleh mengindikasikan bahwa responden memiliki idealisme tinggi. Demikian sebaliknya, semakin kecil nilai yang diperoleh, maka responden memiliki tingkat idealisme yang rendah. Variabel Idealisme $\left(\mathrm{X}_{2}\right)$ memiliki nilai rata-rata sebesar 29,6081 dengan nilai minimum 5,00 dan nilai maksimum 37,38. Hal ini menunjukkan idealisme yang dimiliki oleh mahasiswa akuntansi di Fakultas Ekonomi dan Bisnis Universitas Udayana cukup tinggi. Hal tersebut juga dapat dilihat dari nilai rata-rata lebih mendekati nilai maksimal, yang artinya sebagian 
besar responden cenderung menjawab setuju pada ke-10 item pernyataan dalam variabel idealisme. Nilai standar deviasi yang dimiliki variabel idealisme adalah 8,52740 dimana lebih kecil dari nilai rata-ratanya yaitu 29,6081, sehingga mengindikasikan bahwa hasil yang cukup baik. Hal tersebut dikarenakan standar deviasi adalah pencerminan penyimpangan yang sangat tinggi, sehingga penyebaran data menunjukkan hasil yang normal dan tidak menyebabkan bias.

Variabel relativisme $\left(\mathrm{X}_{3}\right)$ terdiri dari 10 pernyataan mengenai pendapat responden dalam menilai suatu tindakan. Penilaian skor menggunakan skala Likert 1-4, dengan ketentuan semakin besar skor yang diperoleh mengindikasikan bahwa responden memiliki relativisme tinggi. Demikian sebaliknya, semakin kecil nilai yang diperoleh, maka responden memiliki tingkat relativisme yang rendah. Variabel relativisme $\left(\mathrm{X}_{3}\right)$ memiliki nilai ratarata sebesar 22,0654 dengan nilai minimum 12,12 dan nilai maksimum 52,18. Hal ini menunjukkan relativisme yang dimiliki oleh mahasiswa akuntansi di Fakultas Ekonomi dan Bisnis Universitas Udayana cenderung rendah. Hal tersebut juga dapat dilihat dari nilai rata-rata yang cenderung jauh dari nilai maksimal, yang artinya sebagian besar responden cenderung menjawab tidak setuju pada ke-10 item pernyataan dalam variabel relativisme. Nilai standar deviasi yang dimiliki variabel relativisme adalah 7,27105 dimana lebih kecil dari nilai rata-ratanya yaitu 22,0654, sehingga mengindikasikan bahwa hasil yang cukup baik. Hal tersebut dikarenakan standar deviasi adalah pencerminan penyimpangan yang sangat tinggi, sehingga penyebaran data menunjukkan hasil yang normal dan tidak menyebabkan bias. 
Variabel gender $\left(\mathrm{X}_{4}\right)$ diukur menggunakan variabel dummy, dengan kriteria laki-laki diberi skor 0 dan perempuan diberi skor 1. Berdasarkan tabel kriteria gender pada Tabel 1, diketahui bahwa jumlah responden berjenis kelamin perempuan sebanyak 54 orang lebih banyak dari responden laki-laki yang berjumlah 40 orang. Variabel gender memiliki hasil nilai minimum sebesar 1,00 nilai maksimum sebesar 2,00, nilai rata-rata sebesar 1,4255. Nilai standar deviasi yang dimiliki oleh variabel gender adalah 0,49707 dimana lebih kecil dari nilai rata-ratanya yaitu 1,4255, sehingga mengindikasikan bahwa hasil yang cukup baik. Hal tersebut dikarenakan standar deviasi adalah pencerminan penyimpangan yang sangat tinggi, sehingga penyebaran data menunjukkan hasil yang normal dan tidak menyebabkan bias.

Variabel persepsi etis mahasiswa akuntansi atas perilaku tidak etis akuntan (Y) terdiri dari lima buah skenario mengenai konflik kepentingan, penghindaran pajak, pembelian orang dalam, kerahasiaan professional, dan pembayaran kembali. Penilaian skor menggunakan skala Likert 1-4, dengan ketentuan semakin kecil skor yang diperoleh mengindikasikan bahwa responden semakin berpersepsi negatif terhadap perilaku tidak etis akuntan. Demikian sebaliknya, semakin besar nilai yang diperoleh, maka responden semakin berpersepsi positif terhadap perilaku tidak etis akuntan. Variabel persepsi etis mahasiswa akuntansi atas perilaku tidak etis akuntan (Y) memiliki nilai rata-rata sebesar 11,3420 dengan nilai minimum 5,00 dan nilai maksimum 21,95. Hal ini menunjukkan mahasiswa akuntansi di Fakultas Ekonomi dan Bisnis Universitas Udayana memiliki persepsi yang negatif terhadap perilaku 
tidak etis akuntan yang telah terjadi. Hal tersebut juga dapat dilihat dari nilai rata-rata cukup jauh dari nilai maksimal, yang artinya sebagian besar responden cenderung berpersepsi yang negatif terhadap perilaku tidak etis akuntan pada ke-5 item pertanyaan. Nilai standar deviasi yang dimiliki oleh variabel persepsi etis mahasiswa akuntansi atas perilaku tidak etis akuntan adalah 3,90937 dimana lebih kecil dari nilai rata-ratanya yaitu 11,3420, sehingga mengindikasikan bahwa hasil yang cukup baik. Hal tersebut dikarenakan standar deviasi adalah pencerminan penyimpangan yang sangat tinggi, sehingga penyebaran data menunjukkan hasil yang normal dan tidak menyebabkan bias.

Berikut adalah hasil analisis regresi linier berganda yang disajikan pada Tabel 2.

Tabel 2. Hasil uji analisis regresi linier berganda

\begin{tabular}{|c|c|c|c|c|c|}
\hline \multirow[t]{2}{*}{ Model } & \multicolumn{2}{|c|}{ Unstandardized Coefficients } & \multirow{2}{*}{$\begin{array}{c}\text { Standardized } \\
\text { Coefficients } \\
\text { Beta } \\
\end{array}$} & \multirow[t]{2}{*}{$\mathrm{t}$} & \multirow[t]{2}{*}{ Sig. } \\
\hline & B & Std. Error & & & \\
\hline (Constant) & 14,940 & 2,388 & & 6,256 & 0,000 \\
\hline $\mathrm{X}_{1}$ & $-0,079$ & 0,031 & $-0,271$ & $-2,523$ & 0,013 \\
\hline $\mathrm{X}_{2}$ & $-0,108$ & 0,052 & $-0,235$ & $-2,060$ & 0,042 \\
\hline $\mathrm{X}_{3}$ & 0,186 & 0,052 & 0,345 & 3,541 & 0,001 \\
\hline $\mathrm{X}_{4}$ & $-0,582$ & 0,548 & $-0,074$ & $-1,061$ & 0,291 \\
\hline F hitung & \multicolumn{2}{|c|}{$: 31,098$} & & & \\
\hline Signifikansi F & \multicolumn{2}{|c|}{$: 0,000$} & & & \\
\hline R Square & \multicolumn{2}{|c|}{$: 0,583$} & & & \\
\hline Adjusted R Square & \multicolumn{2}{|c|}{$: 0,564$} & & & \\
\hline
\end{tabular}

Berdasarkan hasil analisis yang disajikan pada Tabel 2, maka dapat disusun persamaan regresi m sebagai berikut.

$$
Y=14,940-0,079 X_{1}-0,108 X_{2}+0,186 X_{3}-0,582 X_{4}+\varepsilon
$$

Pengujian pada hipotesis pertama menunjukkan bahwa variabel pengetahuan etika $\left(\mathrm{X}_{1}\right)$ berpengaruh negatif pada persepsi etis mahasiswa 
akuntansi atas perilaku tidak etis akuntan. Signifikansi pengaruh pengetahuan etika pada persepsi etis mahasiswa akuntansi atas perilaku tidak etis akuntan dapat diketahui dengan membandingkan nilai $\mathrm{t}_{\text {sig }}$ dengan $\alpha(0,05)$. Diketahui bahwa nilai t pengetahuan etika $\left(\mathrm{X}_{1}\right)$ sebesar -2,523 dengan signifikansi sebesar 0,013. Nilai signifikansi sebesar $0,013<0,05$ maka hipotesis diterima. Hasil tersebut menunjukkan bahwa secara parsial pengetahuan etika berpengaruh signifikan pada persepsi etis mahasiswa akuntansi atas perilaku tidak etis akuntan. Selain itu, tanda koefisien interaksinya adalah negatif sehingga pengetahuan etika berpengaruh negatif terhadap persepsi etis mahasiswa akuntansi atas perilaku tidak etis akuntan.

Pengujian pada hipotesis kedua menunjukkan bahwa variabel idealisme $\left(\mathrm{X}_{2}\right)$ berpengaruh negatif pada persepsi etis mahasiswa akuntansi atas perilaku tidak etis akuntan. Signifikansi pengaruh idealisme pada persepsi etis mahasiswa akuntansi atas perilaku tidak etis akuntan dapat diketahui dengan membandingkan nilai $t_{\text {sig }}$ dengan $\alpha(0,05)$. Diketahui bahwa nilai $t$ idealisme $\left(\mathrm{X}_{2}\right)$ sebesar $-2,060$ dengan signifikansi sebesar 0,042. Nilai signifikansi sebesar $0,042<0,05$ maka hipotesis diterima. Hasil tersebut menunjukkan bahwa secara parsial idealisme berpengaruh signifikan terhadap persepsi etis mahasiswa akuntansi atas perilaku tidak etis akuntan. Selain itu, tanda koefisien interaksinya adalah negatif sehingga idealisme berpengaruh negatif pada persepsi etis mahasiswa akuntansi atas perilaku tidak etis akuntan.

Pengujian pada hipotesis ketiga menunjukkan bahwa variabel relativisme $\left(\mathrm{X}_{3}\right)$ berpengaruh positif pada persepsi etis mahasiswa akuntansi atas perilaku 
tidak etis akuntan. Signifikansi pengaruh relativisme pada persepsi etis mahasiswa akuntansi atas perilaku tidak etis akuntan dapat diketahui dengan membandingkan nilai $\mathrm{t}_{\text {sig }}$ dengan $\alpha(0,05)$. Diketahui bahwa nilai $\mathrm{t}$ relativisme $\left(\mathrm{X}_{3}\right)$ sebesar 3,541 dengan signifikansi sebesar 0,001. Nilai signifikansi sebesar $0,001<0,05$ maka hipotesis diterima. Hasil tersebut menunjukkan bahwa secara parsial relativisme berpengaruh signifikan terhadap persepsi etis mahasiswa akuntansi atas perilaku tidak etis akuntan. Selain itu, tanda koefisien interaksinya adalah positif sehingga relativisme berpengaruh positif pada persepsi etis mahasiswa akuntansi atas perilaku tidak etis akuntan.

Pengujian pada hipotesis keempat menunjukkan bahwa variabel gender $\left(\mathrm{X}_{4}\right)$ tidak terdapat perbedaan yang signifikan antara responden laki-laki dan perempuan dalam melihat ataupun menilai perilaku tidak etis akuntan. Signifikansi pengaruh gender pada persepsi etis mahasiswa akuntansi atas perilaku tidak etis akuntan dapat diketahui dengan membandingkan nilai $t_{\text {sig }}$ dengan $\alpha(0,05)$. Diketahui bahwa nilai t gender $\left(\mathrm{X}_{4}\right)$ sebesar $-1,061$ dengan signifikansi sebesar 0,291. Nilai signifikansi sebesar 0,291>0,05 maka dapat disimpulkan bahwa antara responden laki-laki dan perempuan memiliki variance yang sama, sehingga $\mathrm{H} 4$ ditolak. Hasil tersebut menunjukkan bahwa secara parsial gender berpengaruh negatif tetapi tidak signifikan pada persepsi etis mahasiswa akuntansi atas perilaku tidak etis akuntan.

Berdasarkan hasil analisis data diperoleh nilai Adjusted $R$ Square sebesar 0,564. Hal ini berarti bahwa sebesar 0,564 atau 56,4\% variasi persepsi etis mahasiswa akuntansi atas perilaku tidak etis akuntan mampu dijelaskan 
oleh variabel pengetahuan etika, idealisme, relativisme, dan gender. Sisanya sebesar 43,6 \% dipengaruhi oleh variabel lain yang tidak masuk dalam model.

Berdasarkan model yang telah dianalisis, diketahui $\mathrm{F}$ hitung sebesar 31,098, signifikansi (p-value) sebesar 0,000. Berdasarkan nilai toleransi yang diberikan yaitu $\alpha=5 \%$ dengan nilai signifikansi $0,000<\alpha(0,05)$, hal ini mengandung arti bahwa seluruh variabel mampu memprediksi atau menjelaskan fenomena persepsi etis mahasiswa akuntansi atas perilaku tidak etis akuntan dan model regresi yang digunakan dianggap layak uji.

Banyaknya informasi yang diperoleh oleh seseorang akan mempengaruhi pengetahuan yang dimiliki. Pengetahuan dapat diperoleh melalui proses belajar secara formal dan informal (lingkungan) maupun berasal dari pengalaman. Pengetahuan memberikan informasi yang bermanfaat untuk mencari solusi atas berbagai permasalahan serta memberikan acuan dalam bertindak di masa sekarang maupun yang akan datang dengan mempelajari peristiwa yang telah terjadi di masa lampau. Pengetahuan etika yang dimiliki seseorang akan memberikan informasi berkaitan dengan suatu etika yang berlaku. Oleh karena itu, seorang yang memiliki pengetahuan etika akan bersikap atau berperilaku sesuai etika yang diketahuinya. Hal tersebut sesuai dengan teori tahapan perkembangan moral, dimana pada usia di atas 13 tahun, seseorang akan cenderung berorientasi pada etika. Semakin banyak atau luas pengetahuan etika yang dimiliki oleh seorang mahasiswa akuntansi, maka semakin rendah persepsi etis mahasiswa akuntansi atas perilaku tidak etis 
akuntan atau kemungkinan untuk melakukan perilaku tidak etis semakin rendah.

Hal ini sesuai dengan penelitian yang dilakukan oleh Damayanthi (2016), Mardawati (2014) dan Herwinda (2010) yang menyatakan bahwa tingkat pengetahuan berpengaruh negatif pada persepsi mahasiswa akuntansi atas perilaku tidak etis akuntan. Namun, hal ini tidak sesuai dengan penelitian yang dilakukan oleh Nugroho (2008) bahwa tingkat pengetahuan tidak berpengaruh terhadap persepsi mahasiswa akuntansi atas tindakan corporate manager dan auditor.

Dalam merespon tindakan dimana perilaku tidak etis akuntan terjadi, seseorang yang bersikap etis seharusnya memberikan jawaban ketidaksetujuan. Orang dengan idealisme yang tinggi akan cenderung menolak atau tidak mentolerir tindakan yang didalamnya terdapat perilaku tidak etis. Hasil penelitian menunjukkan bahwa orang dengan skor idealisme tinggi memberikan skor rendah terhadap perilaku tidak etis. Hal ini berarti bahwa orang dengan idealisme tinggi cenderung tidak setuju atau menolak tindakan yang didalamnya terdapat perilaku tidak etis. Oleh karena itu, semakin tinggi Idealisme maka kemungkinan untuk melakukan tindakan tidak etis semakin rendah. Jadi, mahasiswa dengan idealisme tinggi akan berpersepsi lebih etis atas perilaku tidak etis akuntan. Dalam situasi mengenai perilaku tidak etis yang melibatkan akuntan, seorang yang memiliki idealisme tinggi akan cenderung memberikan tanggapan ketidaksetujuan atas perilaku tidak etis yang terjadi. Hal ini didukung pula oleh Forsyth (1992) dimana orang yang idealis 
mempunyai prinsip bahwa merugikan individu lain adalah hal yang selalu dapat atau harus dihindari dan berpegang teguh pada aturan moral yang bersifat universal. Seorang yang idealis akan memegang teguh perilaku etis di dalam profesi yang mereka jalankan, sehingga individu dengan tingkat idealisme yang tinggi menjadi whistler blower dalam menghadapi situasi yang didalamnya terdapat perilaku tidak etis.

Hasil penelitian ini sesuai dengan penelitian yang dilakukan oleh Marwanto (2007) bahwa idealisme berpengaruh negatif pada persepsi mahasiswa akuntansi atas perilaku tidak etis akuntan. Sejalan dengan hal tersebut, penelitian yang dilakukan oleh Damayanthi (2016) menyatakan bahwa idealisme berpengaruh negatif terhadap persepsi mahasiswa akuntansi atas perilaku tidak etis akuntan. Namun, hasil tersebut tidak sesuai dengan penelitian yang dilakukan oleh Herwinda (2010) bahwa idealisme tidak berpengaruh terhadap persepsi etis mahasiswa akuntansi atas perilaku tidak etis akuntan.

Dalam merespon perilaku tidak etis yang terjadi, seorang dengan relativisme yang tinggi akan cenderung melihat kondisi yang melingkupinya. Apabila hal tersebut merupakan hal yang sudah biasa terjadi, maka seorang dengan relativisme yang tinggi akan menganggap bahwa hal tersebut etis dilakukan. Mereka cenderung mentolerir tindakan yang didalamnya terdapat perilaku tidak etis yang mungkin terjadi. Hasil penelitian menunjukkan bahwa orang dengan skor relativisme tinggi memberikan skor tinggi terhadap perilaku tidak etis yang terjadi. Hal ini berarti bahwa orang dengan relativisme tinggi 
cenderung setuju atau mentolerir adanya perilaku tidak etis. Semakin tinggi relativisme maka kemungkinan untuk melakukan perilaku tidak etis semakin tinggi, sehingga semakin rendah persepsi etis mahasiswa akuntansi atas perilaku tidak etis akuntan.

Lebih lanjut Forsyth \& Nye (1990) dan Forsyth (1992) menyatakan bahwa seorang yang bersifat relativis cenderung menolak prinsip etika universal ketika mengambil suatu keputusan. Suatu tindakan dikatakan etis atau tidak, benar atau salah, tergantung kepada situasi dan sifat individu yang terlibat. Hasil penelitian oleh Damayanthi (2016), Mardawati (2014), dan Herwinda (2010) yang menyatakan bahwa relativisme berpengaruh positif terhadap persepsi etis mahasiswa akuntansi atas perilaku tidak etis akuntan. Namun, hasil ini tidak sesuai dengan penelitian yang dilakukan oleh Nugroho (2008) dan Siti (2006) dimana relativisme tidak berpengaruh terhadap persepsi mahasiswa akuntansi atas tindakan corporate manager dan auditor.

Hasil penelitian menunjukkan bahwa laki-laki dan perempuan memiliki persepsi yang negatif tetapi tidak signifikan atas perilaku tidak etis akuntan. Hal tersebut mengandung arti bahwa laki-laki dan perempuan menunjukkan ketidaksetujuan atas perilaku tidak etis akuntan. Berbeda dengan masa lalu, saat ini kesetaraan gender sangat dijunjung tinggi. Hal ini membuat tidak ada perbedaan antara laki-laki dan perempuan dalam melakukan pekerjaan maupun dalam mengapresiasikan berbagai bidang kehidupan yang ada. Laki-laki dan perempuan dianggap mempunyai hak yang sama. Pola pemikiran perempuan pada zaman dahulu dengan sekarang sedikit berbeda, 
termasuk keberanian dalam bersikap dan mengambil resiko. Dalam menghadapi situasi yang terdapat perilaku tidak etis, perempuan tidak lagi malu-malu seperti dulu. Perempuan saat ini lebih berani dalam menentukan sikap dan mengambil risiko untuk melakukan tindakan yang mendatangkan manfaat bagi dirinya sendiri. Hal ini sesuai dengan pendekatan sosialisasi struktural, dimana laki-laki dan perempuan akan membentuk sikap dan perilaku yang sama dalam merespon hal yang berkaitan dengan perilaku etis.

Hasil ini sejalan dengan penelitian yang dilakukan oleh Damayanthi (2016) dan Diwi (2015) bahwa gender tidak berpengaruh secara signifikan terhadap persepsi mahasiswa mengenai perilaku tidak etis akuntan.

\section{SIMPULAN}

Hasil dalam penelitian ini menunjukkan bahwa pengetahuan etika berpengaruh negatif terhadap persepsi etis mahasiswa akuntansi atas perilaku tidak etis akuntan Hal ini berarti semakin tinggi pengetahuan etika yang dimiliki mahasiswa akuntansi maka semakin rendah pula persepsi etis mahasiswa akuntansi atas perilaku tidak etis akuntan. Hal ini mengandung arti apabila mahasiswa memiliki pengetahuan etika yang tinggi maka akan memberikan reaksi ketidaksetujuan terhadap adanya perilaku tidak etis yang melibatkan akuntan.

Hasil dalam penelitian ini menunjukkan bahwa idealisme berpengaruh negatif terhadap persepsi etis mahasiswa akuntansi atas perilaku tidak etis akuntan Hal ini berarti semakin tinggi idealisme yang dimiliki mahasiswa 
akuntansi maka semakin rendah pula persepsi etis mahasiswa akuntansi atas perilaku tidak etis akuntan. Hal ini mengandung arti apabila mahasiswa memiliki idealisme yang tinggi maka akan memberikan reaksi ketidaksetujuan terhadap adanya perilaku tidak etis yang melibatkan akuntan.

Hasil dalam penelitian ini menunjukkan bahwa relativisme berpengaruh positif terhadap persepsi etis mahasiswa akuntansi atas perilaku tidak etis akuntan. Hal ini berarti semakin tinggi relativisme yang dimiliki mahasiswa akuntansi maka semakin tinggi pula persepsi etis mahasiswa akuntansi atas perilaku tidak etis akuntan. Hal ini mengandung arti apabila mahasiswa memiliki relativisme yang tinggi maka akan memberikan reaksi setuju terhadap adanya perilaku tidak etis yang melibatkan akuntan

Hasil dalam penelitian ini menunjukkan bahwa gender berpengaruh negatif tetapi tidak signifikan pada persepsi etis mahasiswa akuntansi atas perilaku tidak etis akuntan. Hal ini dibuktikan dengan nilai signifikansi variabel gender sebesar 0,291 lebih besar dari 0,05, maka dapat disimpulkan bahwa antara responden laki-laki dan perempuan menunjukkan ketidaksetujuan atas perilaku tidak etis akuntan.

\section{REFERENSI}

Akbar, M. Taufik. 2013. "Analisis Perbedaan Penerapan Etika Profesi Akuntan Dipandang Darisegi Gender Dan Tingkat Pendidikan (Studi Empiris Pada Mahasiswa Akuntansi Di Kota Padang." E-Journal Universitas Negeri Padang.

Bertens, K. 2013. Etika. Yogyakarta: Kanisius.

Communale et. al. 2006. "Professional Etchical Crises: A Case Study of Accounting Majors.” Managerial Auditing Journal 21: 636-56. 
Damayanthi, Putu Dewi Adi. 2016. "Pengaruh Idealisme, Relativisme, Pengetahuan, Gender Dan Umur Pada Perilaku Tidak Etis Akuntan." EJurnal Akuntansi Universitas Udayana 15: 1-16. https://ojs.unud.ac.id/index.php/Akuntansi.

Diwi, dewanti. 2015. "pengaruh orientasi etis dan gender terhadap persepsi mahasiswa mengenai perilaku tidak etis akuntan (studi pada mahasiswa s1 akuntansi universitas negeri Yogyakarta)."

Dzakirin, M. K. 2013. "Orientasi Idealisme, Relativisme, Tingkat Pengetahuan, Dan Gender: Pengaruhnya Pada Persepsi Mahasiswa Tentang Krisis Etika Akuntan Profesional." Jurnal Akuntansi Multiparadigma 2 No.1.

Fitria, Mella. 2015. "Pengaruh Orientasi Idealisme, Relativisme, Tingkat Pengetahuan Akuntansi, Dan Gender Terhadap Persepsi Mahasiswa Akuntansi Tentang Krisis Etika Akuntan Profesional (Studi Empiris Mahasiswa Akuntansi Perguruan Tinggi Di Kota Padang)." E-Journal Universitas Negeri Padang 3 No. 1.

Forsyth, D. 1992. "Judging the Morality of Business Practices: The Influence of Personal Moral Philosophies.” Journal of Business Ethics 11(5): 461-470.

Griffin, R; Moorhead, G. 2014. "Organizational Behavior: Managing People and Organizations: Ricky W. Griffin, Gregory Moorhead, Cengage Learning.”

Himmah, Elok Faiqoh. 2006. "Persepsi Etis Mahasiswa Akuntansi Mengenai Skandal Etis Auditor Dan Corporate Manager." Jurnal Akuntansi Multiparadigma.

Hunt, S. C., C. I. Robert, F. A. Anthony, and dan T.P.C. Marie. 2009. "The Effect Of Gender And Knowledge On Students' Impressions Of Accountants In The Post-Enron Era." Journal of Business \& Economics Research 7(5).

Joseph, Berry and Deshpande. 2010. "Factors That Impact The Ethical Behavior Of College Students. Contemporary Issues In Education Research.” 3 No. 5.

Larkin, J. M. 2000. "The Ability of Internal Auditors to Identify Ethical Dilemmas." Journal of Business Ethics 23: 401-409.

Nugroho, B. 2008. "Faktor-Faktor Yang Mempengaruhi Penilaian Mahasiswa Akuntansi Atas Tindakan Auditor Dan Corporate Manager Dalam Skandal Keuangan Dan Berkarir Di Bidang Akuntansi." E-Journal Universitas Dipenogoro: $1-169$.

Nurcahyo, Immanuel Oky. 2012. "Idealisme, Relativisme, Dan Kreativitas Akuntan.” STIE Perbanas Surabaya 2 No. 1: 73-90. 
Sankaran, S and Bui, T. 2003. "Ethical Attitudes Among Accounting Majors : An Empirical Study." Journal of the American Academy of Business 3 No. 1: pp 71-77.

Sutiarsih, Gusti Ayu, dkk. 2014. "Pengaruh Budaya Etis Organisasi, Idealisme, Dan Relativisme Terhadap Sensitivitas Auditor." Jurnal Ilmiah Mahasiswa Akutansi Undiksha 2 (1): 1-11.

Ziegenfuss, D. E. and Martinson, O. B. 2002. "The IMA Code of Ethics and IMA Members" Ethical Perception and Judgment." Managerial Auditing Journal 17: 165-73. 